\title{
8 Exploring Industry 4.0 production in Sweden
}

\author{
Claudio Fassio and Max Nathan
}

\subsection{Introduction}

Like many industries before it, manufacturing is being 'disrupted' by new technology. This 'Fourth Industrial Revolution' (Schwab, 2017) or 'Industry 4.0' (Brettel et al., 2014) promises substantive productivity and growth effects via the application of technologies such as sensors, nanotech, RFID chips, robotics, machine learning and AI to a vast range of industrial settings (Brynjolfsson and McAfee, 2014). The general purpose nature of many of these technologies (Bresnahan, 2010) is said to promote recombinant growth (Kremer, 1993) both through the reconfiguration of existing production lines, products and services, and the development of entirely new ones.

Much of the existing analysis on the Fourth Industrial Revolution and the implications for the so-called new manufacturing model called Industry 4.0 has focused on users and, more broadly, on industry awareness and levels of readiness in existing businesses (Brettel et al., 2014; Lee et al., 2014, 2015; Schwab, 2017). In contrast, we look at the evolution of Industry 4.0 producers, specifically science and technology companies in Sweden during the 2000s and early 2010s. We use rich microdata from the Swedish MONA dataset to do this, and provide results both at the national level and at the municipality level, identifying clusters in Stockholm and other Swedish cities.

Sweden is a particularly interesting country to study in relation to what Swedish policy makers call smart manufacturing. Its industrial heritage - in particular, its historic strengths in electrical engineering and mobile communications means that hardware firms can potentially draw on a rich 'ecosystem' of high-value manufacturing knowledge, suppliers and collaborators, and a thick labour market of skilled and experienced workers (Brown and Mason, 2014; Spigel, 2017). Unlike Germany, which combines large conglomerates with the 'Mittelstand' of small and medium-size firms, Sweden's industrial economy remains dominated by large MNEs, plus a cadre of specialist ICT consulting companies (Gens et al., 2015; Giertz, 2015a). Furthermore, in the early 2000s, Ericsson shed around 50\% of its workforce: many laid-off workers have either started their own businesses or have moved into consultancy roles, diffusing technical know-how further through the economy (Chaminade et al., 2010). Relatedly, Stockholm has become one of Europe's leading technology hubs, 
with both thousands of young tech companies and some global players such as Skype, Spotify, Mojang and Klarna (Semuels, 2017).

Furthermore, Sweden has a tradition of hands-on industrial policy: national and local policy makers are actively trying to encourage the adoption of new technology across a range of sectors and firm types and a shift towards smart manufacturing. Much of this has been in response to the so-called 'Swedish Paradox' - high levels of R\&D spending but low productivity (Bitard et al., 2008; Ejermo and Kander, 2009), which, it was argued, may be partly explained in Schumpetarian terms by a lack of new entrants who bring new ideas to the market (Aghion et al., 2009).

The chapter is organised as follows. Section 8.2 sets out some key concepts and the country context. Section 8.3 describes our methodology. Section 8.4 discusses results. Section 8.5 gives brief conclusions.

\subsection{Framework}

\subsubsection{Defining Industry 4.0}

'Industry 4.0', the 'Industrial Internet' and the 'Fourth Industrial Revolution' (FIR) are fuzzy terms with no standardised definitions (Giertz,2015a; Gens et al., 2015). Its components can usefully be seen as a 'technology-product-industry space'; that is, an evolving set of technologies, product/service applications and industry specifics.

Commonly cited FIR technologies include sensors and radio chips, AI, machine learning; 3D printing, nanotech and cloud computers. Many of these have general purpose characteristics (Bresnahan, 2010; Perez,2010) and can be applied to a vast range of products and services (Brynjolfsson and McAfee, 2014). These include some wholly new or 'recombinant' use cases (Kremer, 1993), such as new 'smart objects' of varying complexity (such as wearables or drones), as well as existing activities (such as automated production lines), computerised/digitised products (such as medical devices) and components (such as airbags). These new products typically require associated software, in apps and or other control systems. In any given industry, a range of services also builds on these, especially data and analytics around a product (servitisation), consultancy and training.

Almost all manufacturers could be users of these new technologies. We focus on the (smaller) set of producers - firms whose sole or principal output are products in the FIR technology space, or services derived from such products. In practice, these firms cover a number of industries typically considered as science and technology, but also advanced manufacturing, medicine/pharma, consumer electronics and specialised software/support.

\subsubsection{From technologies to ecosystems}

More broadly, and following Freeman (1991) and Perez (2010), we can place these components in a larger, dynamic 'technology system', that is, a set of multiple 
technologies and its linked network of producers, suppliers, distributors and users. Technology systems benefit from (potentially substantial) internal spill-overs. Perez (2010: 187) argues that as 'technologies interconnect and tend to appear in the neighbourhood of other innovations', innovations in one part of the space tend to induce complementary (e.g. downstream) innovations in other parts. These spillovers are likely to exist in both technology space (e.g. recombinant use cases) and physical space (clusters of firms that interact and learn from each other).

Industry 4.0 producers are knowledge-intensive businesses in which symbolic and physical product and service creation is a central activity. As Mudambi (2008) points out, value creation is mostly created at the upstream and downstream ends of a production function: ICTs, in theory, allow ever-finer levels of disaggregation and control. Nevertheless, while the costs of organising across long distances have fallen, the value of physical proximity for complex activity remains high, especially for building relationships, exchanging codified information and observing others (Glaeser, 2011). A number of studies have highlighted tools such as project-based organising (Grabher, 2002), virtual communities (Grabher and Ibert, 2014) and online tools (Bathelt, 2005) to mimic face-to-face interaction. In general, technology companies both make extensive use of these distance-based tools and tightly cluster into urban space (Nathan and Vandore, 2014; Martins, 2015).

How these local and non-local organising dynamics work in the Swedish case is an empirical question. In practice, we can observe co-location straightforwardly through structured data; firm-firm links and relationships are less easy to see.

\subsubsection{The Swedish context}

Sweden has a deep history of involvement in ICT production, especially electronic engineering, as well as closely related fields in advanced manufacturing (Giertz et al., 2015a, 2015b, from which this account draws heavily). Sweden industrialised late compared to its European rivals, but then developed very rapidly, particularly in telecoms: by 1855, for example, there were 5,000 telephone sets in Stockholm, the highest in the world at that time.

In the first half of the twentieth century, Sweden's ICT and manufacturing industries developed through a corporatist national policy framework, with private companies and the state co-creating key technologies and infrastructure, acting as developer and lead customer respectively. Some of these industrial policy bets worked out better than others: the Swedish personal computer industry faded away in the 1980s, for example, but the mobile communications industry did better. By 1969, a common Nordic mobile system had been developed; by 1985, Nordic Mobile Telephony (NMT) was the world's largest mobile network. The pan-European GSM standards group was formed in 1982, with Swedish companies heavily involved in developing the standard for its eventual launch in 1991; it subsequently became a global benchmark for telecoms, helping establish Ericsson as a global ICT player. 
The corporatist policy framework, already under political attack in the 1970s and 1980s, was rolled back substantively during the 1990s after a fiscal crisis, when a number of pro-competition and pro-entrepreneurship policies were also introduced. In 1995 Sweden joined the European Community and deregulated energy, telecoms, postal services and the media, further altering its nationalised/corporatist economic development model.

The early 2000s saw Ericsson, the country's largest ICT firm, enter a period of crisis, driven by the dotcom crash and strategic miscalculations in $3 \mathrm{G}$ technology. By 2004, it had shed around half its workforce, with large job losses in Sweden. These company-level shifts had important knock-on effects in the country. Many laid-off engineers moved into hardware engineering, finance or banking, triggering a wave of entrepreneurship across ICT, especially software and the Internet.

In parallel, national level policy makers in Sweden introduced a number of measures to support new firm formation in the technology sector and other sectors. A policy consensus gradually grew on the need to raise levels of entrepreneurship in the country, especially in high-value activities. A number of subsequent reforms in the 1990 s and 2000s - to tax and competition policy, for example - appear to have helped develop the country's entrepreneurship culture (Semuels, 2017). A national programme also provided subsidised PCs for households, with employers sharing costs; this widely diffused computers into society, including to households that otherwise would have been unable to afford them.Vinnova, the national innovation systems agency, was founded in 2001, as part of a major reorganisation of national economic development institutions. It takes a major interest in Industry 4.0, aiming to connect traditional industries to new digital processes and tools, especially in export industries.

\subsection{Methodology}

Our quantitative analysis uses microdata from the Statistics Sweden MONA database for the years 2007-2012 inclusive. We build industry and municipalitylevel panels from firm and worker-level microdata. The industry-level panel consists of 3,583 4-digit industry*year observations for 2007-2012. The municipality-level panel consists of 1,752 area ${ }^{\star}$ year observations for the same time period. Further details of the build are available on request.

To identify the set of tech firms that are Industry 4.0 producers, we start with a set of 'science and tech' industries drawn from an international benchmarking exercise conducted by the UK Office of National Statistics (Harris, 2015) and defined using 5-digit SICs. Drawing on the framework above, we refine this to proxy 'Industry 4.0 ' producer sectors, dropping a number of content activities (publishing, media, music, advertising) and science/health activities (life sciences, health), except where SIC descriptors directly pertain to $\mathrm{R} \& \mathrm{D}$ and/or manufacturing. We then crosswalk this to 4-digit SICs, which is identical to the NACE Rev 2 /SNI07 codes used in Sweden and other EU Member States. 
We also select a set of STEM occupations from NESTA (Bakhshi et al., 2015), crosswalking these from UK SOC2010 occupation codes to SOC2008, then to the international ISCO08 and ISCO 88 standards. The latter is identical to the SSYK-96 codes used in the Swedish data. Final lists of industries and occupations are given in the appendix, in Tables A1 and A2 respectively.

\subsection{Results}

Table 8.1 compares mean characteristics for the set of Industry 4.0 producing industries against the rest of the economy, pooled across the period 2007-2012. The right-hand column gives the result of a two-tailed T-test on means. We compare across a range of key characteristics in Panels 1 and 2. We can see that in almost all key characteristics, including workforce mix, these industries differ from the rest-of-industry average. Notably, while these industries produce substantively more patents than the rest of Sweden (covering over $75 \%$ of all Swedish patenting - see Table 8.2), and generate substantively higher exports, overall value added and turnover are not significantly different from other Swedish industries. This provides some support to the notion of the Swedish

Table 8.1 Industry 4.0 producers in Sweden: distinctiveness

\begin{tabular}{lrrr}
\hline Variable & \multicolumn{2}{c}{ I4.0 } & \multicolumn{2}{c}{ Rest } & Different? \\
\hline Total firms 5 years old or less & 273,221 & 420,884 & $\mathrm{Y}$ \\
Total large firms & 2,161 & 1,628 & $\mathrm{Y}$ \\
Total SMEs & 882,073 & $1,582,661$ & $\mathrm{Y}$ \\
Total value added (mSEK) & $3,579,333$ & $3,211,102$ & $\mathrm{~N}$ \\
Total net turnover (mSEK) & $13,017,630$ & $11,681,930$ & $\mathrm{~N}$ \\
Total exports value (mSEK) & $4,181,818$ & $1,694,266$ & $\mathrm{Y}$ \\
Total patents weighted by applicants & 13,830 & 3,012 & $\mathrm{Y}$ \\
Total employment & $4,395,439$ & $4,209,906$ & $\mathrm{~N}$ \\
Number of tertiary educated & 826,717 & 636,933 & $\mathrm{Y}$ \\
$\quad$ employees $\leq 3$ yrs & & & \\
Number of tertiary educated & $1,396,159$ & 783,519 & $\mathrm{Y}$ \\
$\quad$ employees $>$ 3 yrs & & & \\
Total STEM workers & 954,285 & 250,847 & $\mathrm{Y}$ \\
Average science workforce intensity & 0.013 & 0.010 & $\mathrm{Y}$ \\
Average engineering workforce & 0.015 & 0.006 & $\mathrm{Y}$ \\
$\quad$ intensity & & & \\
Average tech workforce intensity & 0.037 & 0.013 & $\mathrm{Y}$ \\
Average stem workforce intensity & 0.065 & 0.029 & $\mathrm{Y}$ \\
\hline
\end{tabular}

Source: Statistics Sweden.

Notes: Graduates are those with 3 years or less tertiary education; + postgrads adds in those with more than 3 years tertiary education; STEM occupations defined from NESTA (2015); intensity $=$ share of workers in science/engineering/tech/stem occupations, compared to all workers in these industries; tech industries defined using Harris (2015); turnover, value, added, exports value given in mSEK; patents weighted by applicants. Difference $=$ two-tailed t-test, $5 \%$ significance or better. 
Paradox. We can also see that compared to non tech-industries, 'sci-tech' and Industry 4.0 production have significantly more large firms, fewer start-ups and fewer small and medium-sized enterprises (SMEs).

Importantly, in Panel 3 we compare on the basis of STEM workforce intensity' and its component parts. The concept of workforce intensity draws on the idea of 'creative intensity' widely used in creative economy analysis (Bakshi et al., 2015). This defines a set of 'creative occupations' and then looks at how 'intensively' these are used across different industries. For a given industry $i$, creative intensity is defined as the share of workers in creative occupations in industry $i$ out of all workers in $i$. Here, we substitute creative occupations for scientists, engineers, tech workers and the aggregate set of STEM workers. Again, we can see that Swedish Industry 4.0 producers are distinctive from the rest of Swedish firms in their use of scientists, engineers and technical staff.

Table 8.2 shows the main characteristics of the Industry 4.0 production sectors and covers the period 2007-2012 inclusive.

The top panel looks at workforce characteristics, while the middle and bottom panels cover firm characteristics. For each panel, we show totals by year, percentage change over the period, and these sectors' share of activity across all workers/all firms accordingly. We can see that in 2012, these sectors employed around $18 \%$ of all workers (top panel). Skilled workers make up a disproportionate share of this (these industries employ $21.6 \%$ of all graduates and just under $30 \%$ of all workers with postgraduate qualifications). Not surprisingly, over two-thirds of the country's workers in STEM jobs are employed in these sectors. While these industries' overall workforce share has fallen slightly between 2007 and 2012, shares of skilled and STEM workers have risen, often substantially.

Industry 4.0 production comprises just under 10\% of all firms in Sweden (middle panel). This set of industries has grown by 17\% since 2007 and its composition has changed, with a big rise in SMEs and start-ups, but a fall in large firms (those with over 250 staff). Nevertheless, the sector still contributes over a fifth of all large firms in Sweden. In terms of broader economic performance (bottom panel), turnover, value added and exports are all on an upward trend yet, strikingly, patenting, a key innovation measure, has fallen since 2007.

Our analysis resonates with that of Giertz et al. (2015a), who classify Swedish ICT firms into eight cross-sector verticals. However, they focus on a much narrower range of established ICT firms (2,700 companies that have over five employees) compared with our sample. Within this smaller set, the 'hardware components' and 'complete systems' 'verticals' (closely related industry sets organised around common technologies, products or services) comprise around $14 \%$ of firms and over $20 \%$ of all ICT sector staff (over 26,000 of 132,000 FTE in 2011, compared with 459,000 in our data).

As in our ICT-wide data, hardware activity is a mix of a few large incumbents, plus a long tail of SMEs. The complete systems' vertical is dominated by a few large incumbents, with under 200 firms in total, of which Ericsson accounts for over $70 \%$ of all employees. By contrast, the hardware components' vertical is 
Table 8.2 Industry 4.0 producers in Sweden: time trends

\begin{tabular}{|c|c|c|c|c|}
\hline & Workers & Graduates & + Postgrads & STEM workers \\
\hline 2007 & 464,683 & 85,516 & 135,288 & 90,503 \\
\hline 2008 & 476,401 & 86,365 & 141,980 & 97,519 \\
\hline 2009 & 455,653 & 84,132 & 143,814 & 99,395 \\
\hline 2010 & 445,812 & 85,646 & 147,129 & 100,925 \\
\hline 2011 & 459,503 & 88,853 & 153,370 & 104,161 \\
\hline 2012 & 462,679 & 89,493 & 156,603 & 107,742 \\
\hline$\%$ change 2007-12 & $-0.43 \%$ & $4.65 \%$ & $15.76 \%$ & $19.05 \%$ \\
\hline \multirow[t]{2}{*}{$\%$ all, 2012} & $17.73 \%$ & $21.62 \%$ & $29.97 \%$ & $67.02 \%$ \\
\hline & Firms & Start-ups & SMEs & Large firms \\
\hline 2007 & 87,425 & 27,923 & 86,726 & 238 \\
\hline 2008 & 90,552 & 28,274 & 89,483 & 237 \\
\hline 2009 & 92,683 & 28,439 & 91,395 & 225 \\
\hline 2010 & 87,493 & 27,415 & 85,912 & 221 \\
\hline 2011 & 101,718 & 30,102 & 100,265 & 218 \\
\hline 2012 & 102,606 & 29,703 & 101,043 & 220 \\
\hline$\%$ change 2007-12 & $17.36 \%$ & $6.37 \%$ & $16.51 \%$ & $-7.56 \%$ \\
\hline \multirow{2}{*}{$\%$ all, 2012} & $9.68 \%$ & $11.40 \%$ & $9.67 \%$ & $22.00 \%$ \\
\hline & Turnover & Value added & Exports & Patents \\
\hline 2007 & 390,990 & $1,394,861$ & 443,986 & 1,767 \\
\hline 2008 & 376,374 & $1,427,239$ & 459,208 & 1,690 \\
\hline 2009 & 319,548 & $1,191,571$ & 356,198 & 1,504 \\
\hline 2010 & 381,274 & $1,260,775$ & 410,137 & 1,677 \\
\hline 2011 & 400,075 & $1,465,458$ & 495,151 & 1,518 \\
\hline 2012 & 383,141 & $1,448,182$ & 465,684 & \\
\hline$\%$ change 2007-12 & $-2.01 \%$ & $3.82 \%$ & $4.89 \%$ & $-14.04 \%$ * \\
\hline$\%$ all, 2012 & $19.57 \%$ & $18.67 \%$ & $45.57 \%$ & $76.93 \% \star$ \\
\hline
\end{tabular}

Source: Statistics Sweden.

Notes: Tech industries defined using Harris (2015); graduates are those with 3 years or less tertiary education; + postgrads adds in those with more than 3 years tertiary education; STEM occupations defined from NESTA (2015); start-ups defined as firms 5 years old or less; turnover, value, added, exports value given in $\mathrm{mSEK}$; patents weighted by applicants.

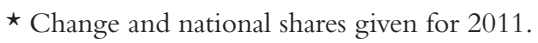

dominated by SMEs, with around ten employees on average; the few large firms have only a few hundred staff. Many of these firms are 'contracting manufacturing'. Many of the newer firms are start-ups producing 'fibre optics, nanotech, power electronics, printed electronics, control equipment, measuring and calibration, antennas, power transistors, alarms, lasers, sensors and actuators', and many are connected to universities.

The other hardware-relevant component of the Swedish ICT industry is R\&D-focused consulting, which in Giertz et al. (2015a) comprised over 360 established firms and almost 12,400 staff in 2011. These firms work with other 
tech businesses on 'pure technical applications', including an important sub-set dealing with embedded systems and the Internet of Things. The roots of this consulting sector lie largely in corporate shake-ups, as discussed above.

\subsubsection{Municipality analysis}

Swedish Industry 4.0 producers are highly clustered, with Stockholm City and County the largest agglomeration of activity. Tables 8.3 and 8.4 give counts, shares and location quotients at municipality level for the years 2007-2012.

Table 8.3 looks at the 20 municipalities with the largest counts of Industry 4.0 firms. Over a quarter of these are in Stockholm County, with Stockholm Municipality having over twice as many firms as the next municipality (Gothenberg), over three times as many Industry 4.0 producer SMEs and around twice as many employees in these industries. Notably, tech SMEs make up almost all of the population of ICT firms and 9-18\% of all SMEs in these municipalities. Stockholm County comprises around $47 \%$ of all Industry 4.0 employment in the 20 most ICT firm-dense municipalities.

Counts and shares do not fully control for the underlying economic structure of areas. Table 8.4 uses location quotients (LQs) to do this for the 20 municipalities with the highest LQs in 2007-2012. Lund has the highest LQ in Sweden in this period; Stockholm city has a rather lower LQ, reflecting its greater economic diversity. However, Stockholm County dominates the table: just under two-thirds of the Sweden's largest tech clusters are in Stockholm municipalities.

Other studies confirm this spatial picture. Chaminade et al. (2010) point to the Kista cluster of large tech MNEs (including Infosys, Huawei and Lenovo) just outside Stockholm city, as nationally important, alongside Skåne County (for computer games) and Linköping (for web servers). Over half the ICT employment identified by Giertz et al. (2015a) is located in Stockholm County $^{1}$ - over 60,000 FTE staff, far fewer than in Table 8.3 given the very restrictive sampling frame of those authors. Six of the eight verticals identified have over half their employees in the area. In hardware systems, Giertz et al. (2015a) highlight the fact that Ericsson has always been critically important to the Stockholm cluster - both through its location in Kista and elsewhere in the metropolitan area, and through its system-wide effects across the county and the country as a whole. Notably, the two least-concentrated sectors identified by Giertz et al. (ibid) are the focus of interest in this study. Around 77\% of hardware components staff work outside Stockholm County, as do 65\% of R\&D-related consultancy staff. However, Stockholm remains the single largest location for these activities.

\subsection{Conclusions}

This chapter uses rich microdata to explore Industry 4.0 production in Sweden, a country with both a rich heritage in advanced manufacturing and an activist public policy tradition. Hardware products and services in Sweden can 
Table 8.3 Firms and workers, top 20 Swedish municipalities by firm counts, 2007-2012

\begin{tabular}{|c|c|c|c|c|c|c|c|c|c|}
\hline \multirow[t]{2}{*}{ Code } & \multirow[t]{2}{*}{ Municipality } & \multirow[t]{2}{*}{ County } & \multicolumn{2}{|c|}{ Sci-tech firms } & \multicolumn{3}{|c|}{ Sci-tech SMEs } & \multicolumn{2}{|c|}{ Sci-tech workers } \\
\hline & & & Total & $\begin{array}{l}\% \text { all } \\
\text { firms }\end{array}$ & Total & $\begin{array}{l}\% \text { all } \\
S M E s\end{array}$ & $\begin{array}{l}\% \text { all } \\
\text { tech }\end{array}$ & Total & $\begin{array}{l}\% \text { all } \\
\text { workers }\end{array}$ \\
\hline 0180 & Stockholm & Stockholm & 17,176 & 13.84 & 17,114 & 14.04 & 99.64 & 121,529 & 17.32 \\
\hline 1480 & Gothenberg & Västra Götaland & 6,881 & 14.32 & 6,853 & 14.51 & 99.59 & 64,989 & 32.93 \\
\hline 1280 & Malmö & Skåne & 3,096 & 12.22 & 3,091 & 12.46 & 99.84 & 12,496 & 14.21 \\
\hline 0380 & Uppsala & Uppsala & 2,353 & 13.43 & 2,351 & 13.64 & 99.92 & 6,932 & 21.19 \\
\hline 1281 & Lund & Skåne & 1,854 & 17.90 & 1,850 & 18.12 & 99.78 & 11,685 & 41.25 \\
\hline 0580 & Linköping & Östergötland & 1,531 & 13.83 & 1,529 & 14.09 & 99.87 & 13,039 & 42.65 \\
\hline 1980 & Västerås & Västmanland & 1,337 & 14.11 & 1,332 & 14.31 & 99.63 & 15,099 & 41.55 \\
\hline 0182 & Nacka & Stockholm & 1,281 & 13.82 & 1,279 & 14.03 & 99.84 & 2,544 & 19.59 \\
\hline 1283 & Helsingborg & Skåne & 1,231 & 10.84 & 1,230 & 11.05 & 99.92 & 4,202 & 12.77 \\
\hline 0160 & Täby & Stockholm & 1,214 & 16.95 & 1,214 & 17.23 & 100.00 & 1,978 & 14.70 \\
\hline 2480 & Umeå & Västerbotten & 1,030 & 9.60 & 1,029 & 9.70 & 99.90 & 2,042 & 10.83 \\
\hline 0184 & Solna & Stockholm & 1,026 & 15.74 & 1,022 & 16.02 & 99.61 & 4,946 & 6.19 \\
\hline 0163 & Sollentuna & Stockholm & 1,014 & 17.35 & 1,014 & 17.63 & 100.00 & 1,855 & 11.13 \\
\hline 0680 & Jönköping & Jönköping & 984 & 9.28 & 979 & 9.40 & 99.49 & 6,291 & 22.05 \\
\hline 0581 & Norrköping & Östergötland & 948 & 10.52 & 946 & 10.70 & 99.79 & 2,908 & 10.33 \\
\hline 1880 & Örebro & Örebro & 889 & 8.50 & 888 & 8.64 & 99.89 & 3,557 & 10.67 \\
\hline 1384 & Kungsbacka & Halland & 888 & 11.43 & 887 & 11.59 & 99.89 & 1,146 & 12.19 \\
\hline 0126 & Huddinge & Stockholm & 878 & 12.14 & 878 & 12.33 & 100.00 & 874 & 7.42 \\
\hline 1490 & Borås & Västra Götaland & 797 & 9.01 & 795 & 9.12 & 99.75 & 4,040 & 17.25 \\
\hline 1780 & Karlstad & Värmland & 783 & 9.92 & 782 & 10.07 & 99.87 & 2,384 & 13.57 \\
\hline
\end{tabular}

Source: Statistics Sweden.

Notes: Tech industries defined using Harris (2015); start-ups defined as firms 5 years old or less. 
Table 8.4 Location quotients, top 20 Swedish municipalities by firm counts, 2007-2012

\begin{tabular}{lllllll}
\hline Code & Municipality & County & Firms & SMEs & Startups & Employees \\
\hline 1281 & Lund & Skåne & 1.856 & 10.370 & 10.187 & 2.256 \\
0163 & Sollentuna & Stockholm & 1.802 & 10.385 & 10.954 & 0.608 \\
0160 & Täby & Stockholm & 1.758 & 10.386 & 10.395 & 0.802 \\
0184 & Solna & Stockholm & 1.632 & 10.349 & 10.447 & 0.346 \\
1262 & Lomma & Skåne & 1.603 & 10.392 & 9.925 & 0.984 \\
1481 & Mölndal & Västra Götaland & 1.601 & 10.378 & 9.214 & 1.054 \\
0183 & Sundbyberg & Stockholm & 1.571 & 10.377 & 11.006 & 0.688 \\
0123 & Järfälla & Stockholm & 1.561 & 10.384 & 10.796 & 0.854 \\
1402 & Partille & Västra & 1.507 & 10.392 & 9.647 & 0.693 \\
& & Götaland & & & & \\
0186 & Lidingö & Stockholm & 1.485 & 10.366 & 10.224 & 1.588 \\
1480 & Göteborg & Västra & 1.484 & 10.349 & 10.554 & 1.793 \\
& $\quad$ Götaland & & & & \\
0162 & Danderyd & Stockholm & 1.467 & 10.366 & 10.025 & 0.949 \\
1980 & Västerås & Västmanland & 1.462 & 10.356 & 11.426 & 2.264 \\
0180 & Stockholm & Stockholm & 1.435 & 10.354 & 10.836 & 0.944 \\
0580 & Linköping & Östergötland & 1.433 & 10.375 & 10.489 & 2.324 \\
0187 & Vaxholm & Stockholm & 1.432 & 10.392 & 10.923 & 0.532 \\
0182 & Nacka & Stockholm & 1.432 & 10.382 & 10.687 & 1.067 \\
0199 & & & 1.415 & 10.392 & 16.330 & 0.934 \\
0117 & Österåker & Stockholm & 1.410 & 10.392 & 10.343 & 0.578 \\
0128 & Salem & Stockholm & 1.403 & 10.392 & 10.122 & 0.382 \\
\hline
\end{tabular}

Source: Statistics Sweden.

Notes: Tech industries defined using ONS/Harris (2015); start-ups defined as firms 5 years old or less.

draw on existing ecosystems, especially in electrical engineering and mobile communications. Swedish Industry 4.0 producers comprised around $10 \%$ of the country's firms in 2012, but around 20\% of all large firms. They employed around $18 \%$ of all workers, but two-thirds of the country's STEM workers. These industries are nationally distinctive in their intensive use of skilled and STEM staff, high levels of patenting, turnover and exports. This setting presents both opportunities and challenges for Sweden as it develops readiness for Industry 4.0 (Nathan, 2018). Industry 4.0 producers can draw on a rich, perhaps unique, ecosystem of high-value knowledge, a web of potential suppliers and large numbers of skilled, experienced workers, much of which is already co-located in a few urban hubs. Unlike competitors such as Germany, in Sweden these industries are also dominated by a few large firms: there are relatively few startups and SMEs, although, as we have shown, their numbers are growing rapidly. Large incumbents are a striking feature of the Swedish ecosystem. They can act as key buyers of new products and services, and potentially partners in product/ firm development. Historically, corporate shocks to large players - notably Ericsson - have helped feed subsequent growth in new entrants. Conversely, large firms in Sweden have tended towards incremental innovation conducted 
internally, which may present coordination problems for joint ventures. On top of policies to promote entrepreneurship and the growth of Stockholm as a leading European tech cluster, this suggests that future Swedish industrial policy will also need to look for tools to promote better links between emerging and existing industry actors in the national ecosystem.

\section{Appendix}

Table A1 List of sci-tech industries 'Science and tech' industries are drawn from an international benchmarking exercise conducted by the UK Office of National Statistics (Harris, 2015)

NACE NACE_descriptor $\quad$ ONS_category

$1920 \quad$ Mineral oil refining

2000 Manufacture of chemicals and chemical products

$2010 \quad$ Manufacture of basic chemicals, fertilisers and nitrogen compounds, plastics and synthetic rubber in primary forms

2011 Manufacture of industrial gases

2012 Manufacture of dyes and pigments

2013 Manufacture of other inorganic basic chemicals

2014 Manufacture of other organic basic chemicals

2015 Manufacture of fertilisers and nitrogen compounds

2016 Manufacture of plastics in primary forms

2017 Manufacture of synthetic rubber in primary forms

2020 Manufacture of pesticides and other agrochemical products

2030 Manufacture of paints, varnishes and similar coatings, mastics and sealants

2040 Manufacture of soap and detergents, cleaning and polishing preparations, perfumes and toilet preparations

2041 Manufacture of cleaning and polishing preparations

2042 Manufacture of perfumes and toilet preparations

2050 Manufacture of other chemical products

2051 Manufacture of explosives other science_tech manufacture

other science_tech manufacture

other science_tech manufacture

other science_tech manufacture

other science_tech manufacture

other science_tech manufacture

other science_tech manufacture

other science_tech manufacture

other science_tech manufacture

other science_tech manufacture

other science_tech manufacture

other science_tech manufacture

other science_tech manufacture

other science_tech manufacture

other science_tech manufacture

other science_tech manufacture

other science_tech manufacture

(continued) 
Table A1 Cont.

\begin{tabular}{|c|c|c|}
\hline NACE & NACE_descriptor & ONS_category \\
\hline 2052 & Manufacture of glues & $\begin{array}{l}\text { other science_tech } \\
\text { manufacture }\end{array}$ \\
\hline 2053 & Manufacture of essential oils & $\begin{array}{l}\text { other science_tech } \\
\text { manufacture }\end{array}$ \\
\hline 2059 & Manufacture of other chemical products n.e.c. & $\begin{array}{l}\text { other science_tech } \\
\text { manufacture }\end{array}$ \\
\hline 2060 & Manufacture of man-made fibres & $\begin{array}{l}\text { other science_tech } \\
\text { manufacture }\end{array}$ \\
\hline 2521 & Manufacture of central heating radiators and boilers & $\begin{array}{l}\text { other science_tech } \\
\text { manufacture }\end{array}$ \\
\hline 2530 & $\begin{array}{l}\text { Manufacture of steam generators, except central heating } \\
\text { hot water boilers }\end{array}$ & $\begin{array}{l}\text { other science_tech } \\
\text { manufacture }\end{array}$ \\
\hline 2540 & Manufacture of weapons and ammunition & $\begin{array}{l}\text { other science_tech } \\
\text { manufacture }\end{array}$ \\
\hline 2610 & Manufacture of electronic components and boards & $\begin{array}{l}\text { digital } \\
\text { technologies }\end{array}$ \\
\hline 2611 & Manufacture of electronic components & $\begin{array}{l}\text { digital } \\
\text { technologies }\end{array}$ \\
\hline 2612 & Manufacture of loaded electronic boards & $\begin{array}{l}\text { digital } \\
\text { technologies }\end{array}$ \\
\hline 2620 & Manufacture of computers and peripheral equipment & $\begin{array}{l}\text { digital } \\
\text { technologies }\end{array}$ \\
\hline 2630 & $\begin{array}{l}\text { Manufacture of communication equipment (other than } \\
\text { telegraph and telephone apparatus and equipment) }\end{array}$ & $\begin{array}{l}\text { publishing and } \\
\text { broadcasting }\end{array}$ \\
\hline 2640 & Manufacture of consumer electronics & $\begin{array}{l}\text { digital } \\
\text { technologies }\end{array}$ \\
\hline 2651 & $\begin{array}{l}\text { Manufacture of non-electronic instruments and appliances } \\
\text { for measuring, testing and navigation, except industrial } \\
\text { process control equipment }\end{array}$ & $\begin{array}{l}\text { other science_tech } \\
\text { manufacture }\end{array}$ \\
\hline 2652 & Manufacture of watches and clocks & $\begin{array}{l}\text { other science_tech } \\
\text { manufacture }\end{array}$ \\
\hline 2660 & $\begin{array}{l}\text { Manufacture of irradiation, electromedical and } \\
\text { electrotherapeutic equipment }\end{array}$ & $\begin{array}{l}\text { life science and } \\
\text { healthcare }\end{array}$ \\
\hline 2670 & $\begin{array}{l}\text { Manufacture of photographic and cinematographic } \\
\text { equipment }\end{array}$ & $\begin{array}{l}\text { publishing and } \\
\text { broadcasting }\end{array}$ \\
\hline 2680 & Manufacture of magnetic and optical media & $\begin{array}{l}\text { digital } \\
\text { technologies }\end{array}$ \\
\hline 2700 & Manufacture of electrical equipment & $\begin{array}{l}\text { other science_tech } \\
\text { manufacture }\end{array}$ \\
\hline 2710 & $\begin{array}{l}\text { Manufacture of electric motors, generators, transformers } \\
\text { and electricity distribution and control apparatus }\end{array}$ & $\begin{array}{l}\text { other science_tech } \\
\text { manufacture }\end{array}$ \\
\hline 2711 & $\begin{array}{l}\text { Manufacture of electric motors, generators and } \\
\text { transformers }\end{array}$ & $\begin{array}{l}\text { other science_tech } \\
\text { manufacture }\end{array}$ \\
\hline 2712 & $\begin{array}{l}\text { Manufacture of electricity distribution and control } \\
\text { apparatus }\end{array}$ & $\begin{array}{l}\text { other science_tech } \\
\text { manufacture }\end{array}$ \\
\hline 2720 & Manufacture of batteries and accumulators & $\begin{array}{l}\text { other science_tech } \\
\text { manufacture }\end{array}$ \\
\hline 2730 & Manufacture of wiring and wiring devices & $\begin{array}{l}\text { other science_tech } \\
\text { manufacture }\end{array}$ \\
\hline
\end{tabular}


Table A1 Cont.

NACE NACE_descriptor

2732 Manufacture of other electronic and electric wires and cables

2733 Manufacture of wiring devices

2740 Manufacture of electric lighting equipment

$2750 \quad$ Manufacture of domestic appliances

2751 Manufacture of electric domestic appliances

2752 Manufacture of non-electric domestic appliances

2790 Manufacture of other electrical equipment

2810 Manufacture of general purpose machinery

2811 Manufacture of engines and turbines, except aircraft, vehicle and cycle engines

2812 Manufacture of fluid power equipment

2813 Manufacture of compressors

2814 Manufacture of other taps and valves

2815 Manufacture of bearings, gears, gearing and driving elements

2821 Manufacture of ovens, furnaces and furnace burners

2822 Manufacture of lifting and handling equipment

2823 Manufacture of office machinery and equipment (except computers and peripheral equipment)

2824 Manufacture of power-driven hand tools

2825 Manufacture of non-domestic cooling and ventilation equipment

2829 Manufacture of other general-purpose machinery n.e.c.

2830 Manufacture of agricultural and forestry machinery

2840 Manufacture of metal forming machinery and machine tools

2841 Manufacture of metal forming machinery

2849 Manufacture of other machine tools

ONS_category

other science_tech manufacture

other science_tech manufacture

other science_tech manufacture

other science_tech manufacture

other science_tech manufacture

other science_tech manufacture

other science_tech manufacture

other science_tech manufacture

other science_tech manufacture

other science_tech manufacture

other science_tech manufacture

other science_tech manufacture

other science_tech manufacture

other science_tech manufacture

other science_tech manufacture

other science_tech manufacture

other science_tech manufacture

other science_tech manufacture

other science_tech manufacture

other science_tech manufacture

other science_tech manufacture

other science_tech manufacture

other science_tech manufacture

other science_tech manufacture

(continued) 
Table A1 Cont.

\begin{tabular}{|c|c|c|}
\hline$N A C E$ & NACE_descriptor & ONS_category \\
\hline 2890 & Manufacture of other special-purpose machinery & $\begin{array}{l}\text { other science_tech } \\
\text { manufacture }\end{array}$ \\
\hline 2891 & Manufacture of machinery for metallurgy & $\begin{array}{l}\text { other science_tech } \\
\text { manufacture }\end{array}$ \\
\hline 2892 & $\begin{array}{l}\text { Manufacture of machinery for mining, quarrying and } \\
\text { construction }\end{array}$ & $\begin{array}{l}\text { other science_tech } \\
\text { manufacture }\end{array}$ \\
\hline 2893 & $\begin{array}{l}\text { Manufacture of machinery for food, beverage and tobacco } \\
\text { processing }\end{array}$ & $\begin{array}{l}\text { other science_tech } \\
\text { manufacture }\end{array}$ \\
\hline 2894 & $\begin{array}{l}\text { Manufacture of machinery for textile, apparel and leather } \\
\text { production }\end{array}$ & $\begin{array}{l}\text { other science_tech } \\
\text { manufacture }\end{array}$ \\
\hline 2895 & $\begin{array}{l}\text { Manufacture of machinery for paper and paperboard } \\
\text { production }\end{array}$ & $\begin{array}{l}\text { other science_tech } \\
\text { manufacture }\end{array}$ \\
\hline 2896 & Manufacture of plastics and rubber machinery & $\begin{array}{l}\text { other science_tech } \\
\text { manufacture }\end{array}$ \\
\hline 2899 & Manufacture of other special-purpose machinery n.e.c. & $\begin{array}{l}\text { other science_tech } \\
\text { manufacture }\end{array}$ \\
\hline 2900 & Manufacture of motor vehicles, trailers and semi-trailers & $\begin{array}{l}\text { other science_tech } \\
\text { manufacture }\end{array}$ \\
\hline 2910 & Manufacture of motor vehicles & $\begin{array}{l}\text { other science_tech } \\
\text { manufacture }\end{array}$ \\
\hline 2920 & $\begin{array}{l}\text { Manufacture of bodies (coachwork) for motor vehicles } \\
\text { (except caravans) }\end{array}$ & $\begin{array}{l}\text { other science_tech } \\
\text { manufacture }\end{array}$ \\
\hline 2930 & Manufacture of parts and accessories for motor vehicles & $\begin{array}{l}\text { other science_tech } \\
\text { manufacture }\end{array}$ \\
\hline 2931 & $\begin{array}{l}\text { Manufacture of electrical and electronic equipment for } \\
\text { motor vehicles }\end{array}$ & $\begin{array}{l}\text { other science_tech } \\
\text { manufacture }\end{array}$ \\
\hline 2932 & $\begin{array}{l}\text { Manufacture of other parts and accessories for motor } \\
\text { vehicles }\end{array}$ & $\begin{array}{l}\text { other science_tech } \\
\text { manufacture }\end{array}$ \\
\hline 3000 & Manufacture of other transport equipment & $\begin{array}{l}\text { other science_tech } \\
\text { manufacture }\end{array}$ \\
\hline 3010 & Building of ships and boats & $\begin{array}{l}\text { other science_tech } \\
\text { manufacture }\end{array}$ \\
\hline 3011 & Building of ships and floating structures & $\begin{array}{l}\text { other science_tech } \\
\text { manufacture }\end{array}$ \\
\hline 3012 & Building of pleasure and sporting boats & $\begin{array}{l}\text { other science_tech } \\
\text { manufacture }\end{array}$ \\
\hline 3020 & Manufacture of railway locomotives and rolling stock & $\begin{array}{l}\text { other science_tech } \\
\text { manufacture }\end{array}$ \\
\hline 3030 & Manufacture of air and spacecraft and related machinery & $\begin{array}{l}\text { other science_tech } \\
\text { manufacture }\end{array}$ \\
\hline 3040 & Manufacture of military fighting vehicles & $\begin{array}{l}\text { other science_tech } \\
\text { manufacture }\end{array}$ \\
\hline 3090 & Manufacture of transport equipment n.e.c. & $\begin{array}{l}\text { other science_tech } \\
\text { manufacture }\end{array}$ \\
\hline 3091 & Manufacture of motorcycles & $\begin{array}{l}\text { other science_tech } \\
\text { manufacture }\end{array}$ \\
\hline 3092 & Manufacture of bicycles and invalid carriages & $\begin{array}{l}\text { other science_tech } \\
\text { manufacture }\end{array}$ \\
\hline
\end{tabular}


Table A1 Cont.

\begin{tabular}{|c|c|c|}
\hline NACE & NACE_descriptor & ONS_category \\
\hline 3099 & Manufacture of other transport equipment n.e.c. & $\begin{array}{l}\text { other science_tech } \\
\text { manufacture }\end{array}$ \\
\hline 3212 & Manufacture of jewellery and related articles & $\begin{array}{l}\text { other science_tech } \\
\text { manufacture }\end{array}$ \\
\hline 3240 & Manufacture of professional and arcade games and toys & $\begin{array}{l}\text { other science_tech } \\
\text { manufacture }\end{array}$ \\
\hline 3250 & $\begin{array}{l}\text { Manufacture of medical and dental instruments and } \\
\text { supplies }\end{array}$ & $\begin{array}{l}\text { life science and } \\
\text { healthcare }\end{array}$ \\
\hline 3312 & Repair of machinery & $\begin{array}{l}\text { other science_tech } \\
\text { manufacture }\end{array}$ \\
\hline 3313 & Repair of electronic and optical equipment & $\begin{array}{l}\text { digital } \\
\text { technologies }\end{array}$ \\
\hline 3314 & Repair of electrical equipment & $\begin{array}{l}\text { other science_tech } \\
\text { manufacture }\end{array}$ \\
\hline 3315 & Repair and maintenance of ships and boats & $\begin{array}{l}\text { other science_tech } \\
\text { manufacture }\end{array}$ \\
\hline 3316 & Repair and maintenance of aircraft and spacecraft & $\begin{array}{l}\text { other science_tech } \\
\text { manufacture }\end{array}$ \\
\hline 3317 & Repair and maintenance of other transport equipment & $\begin{array}{l}\text { other science_tech } \\
\text { manufacture }\end{array}$ \\
\hline 5100 & Air transport & $\begin{array}{l}\text { other science_tech } \\
\text { services }\end{array}$ \\
\hline 5110 & Scheduled passenger air transport & $\begin{array}{l}\text { other science_tech } \\
\text { services }\end{array}$ \\
\hline 5120 & Freight air transport and space transport & $\begin{array}{l}\text { other science_tech } \\
\text { services }\end{array}$ \\
\hline 5121 & Freight air transport & $\begin{array}{l}\text { other science_tech } \\
\text { services }\end{array}$ \\
\hline 5122 & Space transport & $\begin{array}{l}\text { other science_tech } \\
\text { services }\end{array}$ \\
\hline 5820 & Software publishing & $\begin{array}{l}\text { digital } \\
\quad \text { technologies }\end{array}$ \\
\hline 5821 & Publishing of computer games & $\begin{array}{l}\text { digital } \\
\text { technologies }\end{array}$ \\
\hline 5829 & Other software publishing & $\begin{array}{l}\text { digital } \\
\text { technologies }\end{array}$ \\
\hline 6200 & Computer programming, consultancy and related activities & $\begin{array}{l}\text { digital } \\
\text { technologies }\end{array}$ \\
\hline 6201 & Computer programming activities & $\begin{array}{l}\text { digital } \\
\text { technologies }\end{array}$ \\
\hline 6202 & Computer consultancy activities & $\begin{array}{l}\text { digital } \\
\quad \text { technologies }\end{array}$ \\
\hline 6203 & Computer facilities management activities & $\begin{array}{l}\text { digital } \\
\text { technologies }\end{array}$ \\
\hline 6209 & $\begin{array}{l}\text { Other information technology and computed service } \\
\text { activities }\end{array}$ & $\begin{array}{l}\text { digital } \\
\text { technologies }\end{array}$ \\
\hline 6310 & Data processing, hosting and related activities; web portals & $\begin{array}{l}\text { digital } \\
\quad \text { technologies }\end{array}$ \\
\hline
\end{tabular}


Table A1 Cont.

\begin{tabular}{|c|c|c|}
\hline NACE & NACE_descriptor & ONS_category \\
\hline 6311 & Data processing, hosting and related activities & $\begin{array}{l}\text { digital } \\
\text { technologies }\end{array}$ \\
\hline 6312 & Web portals & $\begin{array}{l}\text { digital } \\
\text { technologies }\end{array}$ \\
\hline 7100 & $\begin{array}{l}\text { Architectural and engineering activities; technical testing } \\
\text { and analysis }\end{array}$ & $\begin{array}{l}\text { other science_tech } \\
\text { services }\end{array}$ \\
\hline 7110 & $\begin{array}{l}\text { Architectural and engineering activities and related } \\
\text { technical consultancy }\end{array}$ & $\begin{array}{l}\text { other science_tech } \\
\text { services }\end{array}$ \\
\hline 7111 & Architectural activities & $\begin{array}{l}\text { other science_tech } \\
\text { services }\end{array}$ \\
\hline 7112 & Engineering activities and related technical consultancy & $\begin{array}{l}\text { other science_tech } \\
\text { services }\end{array}$ \\
\hline 7120 & Technical testing and analysis & $\begin{array}{l}\text { other science_tech } \\
\text { services }\end{array}$ \\
\hline 7219 & $\begin{array}{l}\text { Other research and experimental development on natural } \\
\text { sciences and engineering }\end{array}$ & $\begin{array}{l}\text { other science_tech } \\
\text { services }\end{array}$ \\
\hline 7220 & $\begin{array}{l}\text { Research and experimental development on social } \\
\text { sciences and humanities }\end{array}$ & $\begin{array}{l}\text { other science_tech } \\
\text { services }\end{array}$ \\
\hline 7490 & Quantity surveying activities & $\begin{array}{l}\text { other science_tech } \\
\text { services }\end{array}$ \\
\hline 8540 & Higher education & $\begin{array}{l}\text { other science_tech } \\
\text { services }\end{array}$ \\
\hline 8541 & Post-secondary non-tertiary education & $\begin{array}{l}\text { other science_tech } \\
\text { services }\end{array}$ \\
\hline 8542 & Tertiary education & $\begin{array}{l}\text { other science_tech } \\
\text { services }\end{array}$ \\
\hline 9511 & Repair of computers and peripheral equipment & $\begin{array}{l}\text { digital } \\
\text { technologies }\end{array}$ \\
\hline 9521 & Repair of consumer electronics & $\begin{array}{l}\text { other science_tech } \\
\text { manufacture }\end{array}$ \\
\hline 9522 & $\begin{array}{l}\text { Repair of household appliances and home and garden } \\
\text { equipment }\end{array}$ & $\begin{array}{l}\text { other science_tech } \\
\text { manufacture }\end{array}$ \\
\hline 9525 & Repair of watches, clocks and jewellery & $\begin{array}{l}\text { other science_tech } \\
\text { manufacture }\end{array}$ \\
\hline
\end{tabular}

Note:The ONS set of industries is defined at 5- digit SIC2007 level. I refine this to focus on Industry 4.0, dropping a number of content activities (publishing, media, music, advertising) and science / health activities (life sciences, health), except where SIC descriptors directly pertain to R\&D and/ or manufacturing. We then crosswalk this to 4- digit SIC, which is identical to the NACE Rev 2 / SNI07 codes used in Sweden and other EU states. 
Table A2 List of STEM occupations STEM occupations are taken from NESTA (Bakhshi et al., 2015)

\begin{tabular}{|c|c|c|}
\hline Category & ISCO88 & ISCO88_descriptor \\
\hline IT & 1226 & $\begin{array}{l}\text { Production and Operations Department Managers } \\
\text { in Transport, Storage and Communications }\end{array}$ \\
\hline IT & 1236 & Computing Services Department Managers \\
\hline IT & 1316 & $\begin{array}{l}\text { General Managers in Transport, Storage and } \\
\text { Communications }\end{array}$ \\
\hline IT & 1317 & General Managers of Business Services \\
\hline Science & 2113 & Chemists \\
\hline Science & 2211 & $\begin{array}{l}\text { Biologists, Botanists, Zoologists and Related } \\
\text { Professionals }\end{array}$ \\
\hline Science & 2212 & $\begin{array}{l}\text { Pharmacologists, Pathologists and Related } \\
\text { Professionals }\end{array}$ \\
\hline Science & 2111 & Physicists and Astronomers \\
\hline Science & 2114 & Geologists and Geophysicists \\
\hline Science & 2211 & $\begin{array}{l}\text { Biologists, Botanists, Zoologists and Related } \\
\text { Professionals }\end{array}$ \\
\hline Science & 2212 & $\begin{array}{l}\text { Pharmacologists, Pathologists and Related } \\
\text { Professionals }\end{array}$ \\
\hline Engineering & 2142 & Civil Engineers \\
\hline Engineering & 2144 & Mechanical Engineers \\
\hline Engineering & 2143 & Electrical Engineers \\
\hline Engineering & 2144 & Electronics and Telecommunications Engineers \\
\hline Engineering & 2149 & $\begin{array}{l}\text { Architects, Engineers and Related Professionals Not } \\
\text { Elsewhere Classified }\end{array}$ \\
\hline Engineering & 2149 & $\begin{array}{l}\text { Architects, Engineers and Related Professionals } \\
\text { NEC }\end{array}$ \\
\hline Engineering & 2150 & $\begin{array}{l}\text { Architects, Engineers and Related Professionals } \\
\text { NEC }\end{array}$ \\
\hline IT & 2131 & Computer Systems Designers and Analysts \\
\hline IT & 2132 & Computer Programmers \\
\hline IT & 2139 & Computing Professionals NEC \\
\hline IT & 2131 & Computer Systems Designers and Analysts \\
\hline IT & 2132 & Computer Systems Designers and Analysts \\
\hline IT & 2131 & Computer Systems Designers and Analysts \\
\hline IT & 2132 & Computer Programmers \\
\hline IT & 2139 & Computing Professionals NEC \\
\hline IT & 2131 & Computer Systems Designers and Analysts \\
\hline IT & 2132 & Computer Programmers \\
\hline IT & 2139 & Computing Professionals NEC \\
\hline Science & 2211 & $\begin{array}{l}\text { Biologists, Botanists, Zoologists and Related } \\
\text { Professionals }\end{array}$ \\
\hline Science & 2212 & $\begin{array}{l}\text { Biologists, Botanists, Zoologists and Related } \\
\text { Professionals }\end{array}$ \\
\hline Science & 1237 & Research and Development Department Managers \\
\hline Science & 1319 & General Managers NEC \\
\hline Engineering & 2148 & Cartographers and Surveyors \\
\hline
\end{tabular}

Note: I crosswalk these from UK SOC2010 occupation codes to SOC2008, then to the international ISCO08 and ISCO 88 standards. The latter is identical to the SSYK-96 codes used in the Swedish data. 


\section{Note}

1 Stockholm County consists of 26 municipalities, out of 290 municipalities, and there are 20 counties in the whole of Sweden.

\section{References}

Aghion, P., Blundell, R., Griffith, R. et al. (2009) The effects of entry on incumbent innovation and productivity. Review of Economics and Statistics 91: 20-32.

Bakhshi, H., Davies, J., Freeman, A., et al. (2015) The Geography of the UK's Creative and High-Tech Economies. London: NESTA.

Bathelt, H. (2005) Geographies of production: growth regimes in spatial perspective (II) - knowledge creation and growth in clusters. Progress in Human Geography 29: 204-216.

Bitard, P., Edquist, C., Hommen, L. et al. (2008) Reconsidering the paradox of high R\&D input and low innovation: Sweden. In: Edquist C. and Hommen L. (eds), Small Country Innovation Systems: Globalization, Change and Policy in Asia and Europe. Cheltenham: Edward Elgar, 237-280.

Bresnahan, T. (2010) General purpose technologies. In: Hall B.H. and Rosenberg N. (eds), Handbook of the Economics of Innovation. Amsterdam: North-Holland, 761-791.

Brettel, M., Friederichsen, N., Keller, M. et al. (2014) How virtualization, decentralization and network building change the manufacturing landscape: an Industry 4.0 oerspective. International Journal of Mechanical, Industrial Science and Engineering 8: $37-44$.

Brown, R. and Mason, C. (2014) Inside the high-tech black box: a critique of technology entrepreneurship policy. Technovation 34: 773-784.

Brynjolfsson, E. and McAfee (2014) The Second Machine Age: Work, Progress, and Prosperity in a Time of Brilliant Technologies. New York: W.W. Norton \& Company.

Chaminade, C., Zabala, J.M. and Treccani, A. (2010) The Swedish national innovation system and its relevance for the emergence of global innovation networks. CIRCLE Working Paper 2010/09. Lund: CIRCLE.

Ejermo, O. and Kander, A. (2009) The Swedish paradox revisited. In: Karlsson C., Johansson B. and Stough R. (eds), Entrepreneurship and Innovation in Functional Regions. Cheltenham: Edward Elgar, pp. 49-76.

Freeman, C. (1991) Networks of innovators: a synthesis of research issues. Research Policy 20: 499-514.

Gens, M., Giertz, E. and Rickne, A. (2015) ICT related technology shifts in the engineering sector. In: Giertz E., Rickne A. and Rouvinen P. (eds), Small and Beautiful: The ICT Success of Finland \& Sweden. Stockholm: Vinnova, pp. 183-199.

Giertz, E. (2015a) The Swedish ICT sector today. In: Giertz E., Rickne A. and Rouvinen P. (eds), Small and Beautiful: The ICT Success of Finland \& Sweden. Stockholm: Vinnova, pp. 106-121.

Giertz, E. (2015b) Understanding the Swedish saga through an historical exposé. In: Giertz E., Rickne A. and Rouvinen P. (eds), Small and Beautiful: The ICT Success of Finland \& Sweden. Stockholm: Vinnova, pp. 62-95.

Glaeser, E. (2011) The Triumph of the City. London: Pan Macmillan. 
Grabher, G. (2002) Cool projects, boring institutions: temporary collaboration in social context. Regional Studies 36: 205-214.

Grabher, G. and Ibert, O. (2014) Distance as asset? Knowledge collaboration in hybrid virtual communities. Journal of Economic Geography 14: 97-123.

Harris, J. (2015) Identifying Science and Technology Businesses in Official Statistics. London: ONS.

Kremer, M. (1993) The O-ring theory of economic development. Quarterly Journal of Economics 108: 551-575.

Lee, J., Bagheri, B. and Kao, H.-A. (2015) A cyber-physical systems architecture for Industry 4.0-based manufacturing systems. Manufacturing Letters 3: 18-23.

Lee, J., Kao, H.-A. andYang, S. (2014) Service innovation and smart analytics for Industry 4.0 and big data environment. Procedia CIRP 16: 3-8.

Martins, J. (2015) The extended workplace in a creative cluster: exploring space(s) of digital work in silicon roundabout. Journal of Urban Design 20: 25-145.

Mudambi, R. (2008) Location, control and innovation in knowledge-intensive industries. Journal of Economic Geography 8: 699-725.

Nathan, M. (2018) 'Hardware is hard': manufacturing startups in an urban technology clusters. MAKERS working paper.

Nathan, M. and Vandore, E. (2014) Here be startups: exploring London's 'Tech City' digital cluster. Environment and Planning A 46: 2283-2299.

Perez, C. (2010) Technological revolutions and techno-economic paradigms. Cambridge Journal of Economics 34: 185-202.

Schwab, K. (2017) The Fourth Industrial Revolution. London: Crown Business.

Semuels, A. (2017) Why does Sweden have so many start-ups? The Atlantic, 28 September.

Spigel, B. (2017) The relational organization of entrepreneurial ecosystems. Entrepreneurship Theory and Practice 41: 49-72. 